\title{
The effects of different loading doses of dexmedetomidine on sedation
}

\author{
Jae Hwan Sim, Hyun Jeong Yu, and Sang Tae Kim \\ Department of Anesthesiology and Pain Medicine, Chungbuk National University College of Medicine, Cheongju, Korea
}

Background: Dexmedetomidine is a useful sedative drug with various uses. We designed this study to investigate the clinical effects and complications of different loading doses, 0.5 and $1.0 \mu \mathrm{g} / \mathrm{kg}$.

Methods: Forty six patients, of American Society of Anesthesiologists physical status I and II, who required elective and emergency operation under spinal anesthesia were randomly assigned to group L or group H. Group L received a loading dose of $0.5 \mu \mathrm{g} / \mathrm{kg}$ for 10 minutes while group $\mathrm{H}$ received $1.0 \mu \mathrm{g} / \mathrm{kg}$. Bispectral index (BIS), systolic blood pressure, heart rate, and Ramsay score were recorded at $\mathrm{T}_{0}$ (before loading), $\mathrm{T}_{\mathrm{L}}$ (just after loading) and $\mathrm{T}_{10,20,30}\left(10,20,30\right.$ minutes after $\mathrm{T}_{\mathrm{L}}$ ). Complications, drug use, lowest BIS and time to reach BIS 80 after termination of dexmedetomidine were recorded during this study.

Results: In group H, BIS value decreased significantly after $T_{L}$ compared to the baseline $\left(T_{0}\right)$, while in group $L$ after $T_{10}$. Between two groups, BIS values showed a significant differences only at $\mathrm{T}_{10}$, BIS of group $\mathrm{H}$ was lower than that of group L. Ramsay score showed no significant differences except in $\mathrm{T}_{\mathrm{L}}$; the score of group $\mathrm{L}$ was significantly lower than that of group $\mathrm{H}$. Other vital signs and complications showed a minimal differences between two groups.

Conclusions: Higher loading dose $(1.0 \mu \mathrm{g} / \mathrm{kg})$ of dexmedetomidine can lead to faster sedation without any severe complications. (Korean J Anesthesiol 2014; 67: 8-12)

Key Words: Conscious sedation, Dexmedetomidine.

Received: November 4, 2013. Revised: 1st, December 4, 2013; 2nd, December 19, 2013. Accepted: December 20, 2013.

Corresponding author: Sang Tae Kim, M.D., Department of Anesthesiology and Pain Medicine, Chungbuk National University College of Medicine, 776, 1sunhwan-ro, Heungdeok-gu, Cheongju 361-711, Korea. Tel: 82-43-269-6237, Fax: 82-43-272-0264, E-mail: kimst@chungbuk.ac.kr (c) This is an open-access article distributed under the terms of the Creative Commons Attribution Non-Commercial License (http:// creativecommons.org/licenses/by-nc/3.0/), which permits unrestricted non-commercial use, distribution, and reproduction in any medium, provided the original work is properly cited. 


\section{Introduction}

Dexmedetomidine is a highly selective alpha 2 agonist [1]. This drug activates alpha 2 receptors in the locus ceruleus of the brain, resulting in very effective sedation of the patient [2]. Unlike many other sedative drugs that cause respiratory depression during sedation, dexmedetomidine is free from such side effects [3-6]. This advantage contributes to the variable use of dexmedetomidine, not only in the critical care unit as originally intended, but also in sedation and anesthesia in both preoperative and postoperative periods [7].

However, this alpha 2 agonist has its own side effects. Activation of the alpha 2 receptors in peripheral vessels causes unexpected hypertension and bradycardia during the first few minutes of infusion, and the converse may occur after this period: rebound of the autonomic nervous system can result in hypotension and tachycardia $[8,9]$.

The dosing of dexmedetomidine varies based on its purpose, although clinical use usually suggests a loading dose of $0.5-1.0$ $\mu \mathrm{g} / \mathrm{kg}$ for 10 minutes and a maintenance dose of $0.2-0.7 \mu \mathrm{g} / \mathrm{kg} / \mathrm{min}$ [7]. We designed this study to investigate the clinical effects and complications at two different loading doses, 0.5 and $1.0 \mu \mathrm{g} / \mathrm{kg}$.

\section{Materials and Methods}

Forty six patients, of American Society of Anesthesiologists physical status I and II, who required elective and emergency operation under spinal anesthesia were enrolled in this prospective, randomized, double-blind study. The exclusion criteria were underlying neurologic and cardiovascular disease, renal failure, liver failure and contraindication cases of spinal anesthesia such as bleeding tendency, patient refusal. The study was approved by the Institutional Review Board and written informed consent was obtained from each patient.

All patients fasted for 8 hours before the operation, and no premedications were administered. In the operating room, 5 $\mathrm{L} / \mathrm{min}$ of oxygen was provided to patients via an oxygen mask and an intravenous line was placed in each patient's forearm. Before spinal anesthesia, Ringer's lactate solution $10 \mathrm{ml} / \mathrm{kg}$ was administered intravenously as pre-hydration. The patients were placed in the lateral decubitus position and spinal punctures were performed using a 25-gauge Quincke spinal needle at $\mathrm{L}_{3-4}$ or $\mathrm{L}_{4-5}$. Hyperbaric $0.5 \%$ bupivacaine $12 \mathrm{mg}$ was administered intrathecally and lied down immediately. In all patients, spinal anesthesia was successfully conducted, and sensory block level was evaluated in pin prick test by using $25 \mathrm{G}$ needle. After wiping the patient's forehead with alcohol gauze, a BIS monitor (Model A 3000, Aspect Medical systems, Natick, MA, USA) was placed and the initial BIS value was recorded. Heart rate (HR), oxygen saturation $\left(\mathrm{SpO}_{2}\right)$, non-invasive blood pressure, Ramsay
Table 1. Ramsay Sedation Scale

\begin{tabular}{cl}
\hline Sedation level & \multicolumn{1}{c}{ Description } \\
\hline 1 & Patient is anxious, agitated or restless, or both \\
2 & Patient is cooperative, oriented, and tranquil \\
3 & Patient responds only to commands \\
4 & Patient responds to light glabellar tap or loud auditory \\
& stimulus \\
5 & Patient has a sluggish response to light glabellar tap or \\
& loud auditory stimulus \\
\hline
\end{tabular}

score (Table 1) and BIS were closely monitored in all patients, before administration of the loading dose of dexmedetomidine $\left(\mathrm{T}_{0}\right)$, just after loading $\left(\mathrm{T}_{\mathrm{L}}\right)$, and at $10 \mathrm{~min}$ intervals thereafter $\left(\mathrm{T}_{10}, \mathrm{~T}_{20}, \mathrm{~T}_{30}\right)[10]$.

Loading was started immediately after 20 minutes in a manner corresponding to the loading dose of each group: group $\mathrm{H}$ with $1.0 \mu \mathrm{g} / \mathrm{kg}$ and group $\mathrm{L}$ with $0.5 \mu \mathrm{g} / \mathrm{kg}$. After 10 minutes of loading, dosing was changed to a maintenance dose, $0.5 \mu \mathrm{g} / \mathrm{kg} /$ min. All data were recorded every 10 minutes until the end of the operation.

After the operation, infusion of dexmedetomidine was stopped. The lowest BIS score during the operation and the time to reach BIS 80 after termination of infusion were recorded.

Aside from the primary data, all complications were recorded when they occurred. Complications were defined as hypertension (systolic blood pressure or mean arterial pressure $>20 \%$ of baseline), hypotension (systolic blood pressure $<80 \mathrm{mmHg}$ ), bradycardia (heart rate $<50$ beats/min), tachycardia (heart rate $>100$ beats/min for 5 minutes), hypoxemia $\left(\mathrm{SpO}_{2}<95 \%\right)$ and oral dryness. Ephedrine and atropine used for the rescue of such complications were also recorded after each use.

All measures were displayed as mean \pm standard deviation (SD). When BIS had a difference of 10 or more, the a value was set at 0.05 , the $\beta$ value was set at 0.2 and the sample size was set at 23 .

Statistical analysis was performed using R 3.0.0. for Windows. Enumeration data such as sex, incidence of side effects and use of drugs were compared with Chi-square analysis. Nonenumeration data such as BIS, SBP, and HR were compared by Student's t-test. $\mathrm{P}$ values less than 0.05 were considered statistically significant.

\section{Results}

Forty-six patients were enrolled in this study. No patients were excluded and patient characteristics such as sex, age, height, weight and sensory block level showed no significant differences between two groups (Table 2).

In group $\mathrm{H}, \mathrm{BIS}$ value decreased significantly after $\mathrm{T}_{\mathrm{L}}$ com- 
Table 2. Patient Characteristics

\begin{tabular}{lcc}
\hline & $\begin{array}{c}\text { Group H } \\
(\mathrm{n}=23)\end{array}$ & $\begin{array}{c}\text { Group L } \\
(\mathrm{n}=23)\end{array}$ \\
\hline Gender $(\mathrm{M} / \mathrm{F})$ & $11 / 12$ & $12 / 11$ \\
Age $(\mathrm{yr})$ & $49 \pm 13.9$ & $43.7 \pm 18.6$ \\
Weight $(\mathrm{kg})$ & $63 \pm 13$ & $68.3 \pm 12.3$ \\
Height $(\mathrm{cm})$ & $162.9 \pm 11.5$ & $166.2 \pm 9.6$ \\
Sensory block level & $7.2 \pm 2.0$ & $7.7 \pm 2.4$ \\
$\quad$ (Thoracic dermatome) & & \\
\hline
\end{tabular}

Values are mean \pm SD or number of patients. There are no significant differences between two groups. Group L: loading dose $0.5 \mu \mathrm{g} / \mathrm{kg}$, Group H: loading dose $1.0 \mu \mathrm{g} / \mathrm{kg}$.

Table 3. Complications, Drug Use, Minimal BIS and Time to Reach BIS 80

\begin{tabular}{lcc}
\hline & Group H & Group L \\
\hline Bradycardia & 3 & 4 \\
Hypoxemia & 0 & 0 \\
Hypertension & 2 & 1 \\
Hypotension & 1 & 2 \\
BISmin & $54.1 \pm 17.8$ & $57.7 \pm 15.5$ \\
Time to reach BIS $80(\mathrm{sec})$ & $145.7 \pm 213$ & $56.7 \pm 71$ \\
\hline
\end{tabular}

Values are mean \pm SD or number of patients. There are no significant differences between two groups. Group L: loading dose $0.5 \mu \mathrm{g} / \mathrm{kg}$, Group H: loading dose $1.0 \mu \mathrm{g} / \mathrm{kg}$. BISmin: Lowest value of BIS during the study.

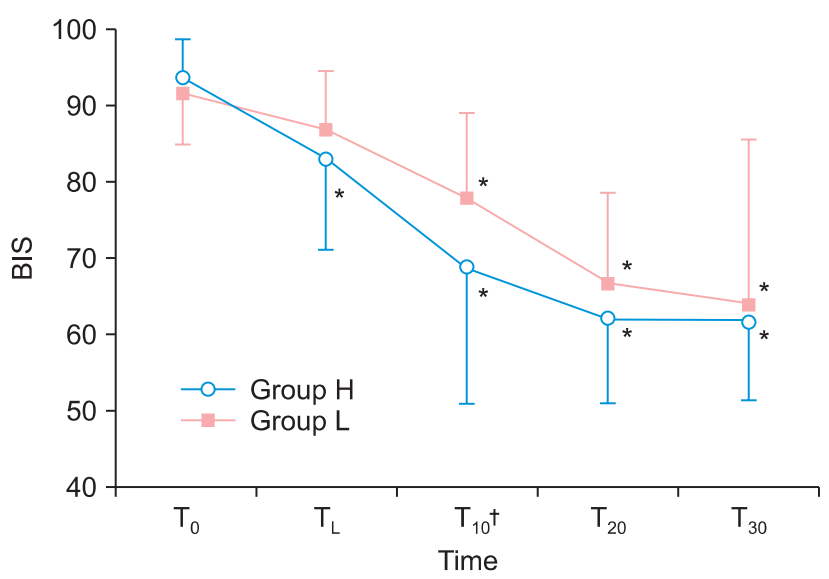

Fig. 1. Bispectral index during sedation. ${ }^{*} \mathrm{P}<0.05$ compared to $\mathrm{T}_{0}$, ${ }^{\dagger} \mathrm{P}<0.05$ between two groups, Group L: loading dose $0.5 \mu \mathrm{g} / \mathrm{kg}$, Group $\mathrm{H}$ : loading dose $1.0 \mu \mathrm{g} / \mathrm{kg}, \mathrm{T}_{0}$ : start of anesthesia, $\mathrm{T}_{\mathrm{L}}$ : after loading, $\mathrm{T}_{10}$ : 10 minutes after $\mathrm{T}_{\mathrm{L}}, \mathrm{T}_{20}: 20$ minutes after $\mathrm{T}_{\mathrm{L}}, \mathrm{T}_{30}: 30$ minutes after $\mathrm{T}_{\mathrm{L}}$.

pared to the baseline $\left(\mathrm{T}_{0}\right)$, while in group $\mathrm{L}$ after $\mathrm{T}_{10}$ (Fig. 1). Between two groups, BIS values showed a significant differences only at $\mathrm{T}_{10}$, BIS of group $\mathrm{H}$ was lower than that of group $\mathrm{L}$. However, the other BIS parameters (the lowest BIS value and time to reach BIS 80) did not show any significant differences between two groups (Table 3 ).

Throughout this study, heart rate decreased significantly rather than $\mathrm{T}_{0}$ value in the both groups. But, there were no sig-

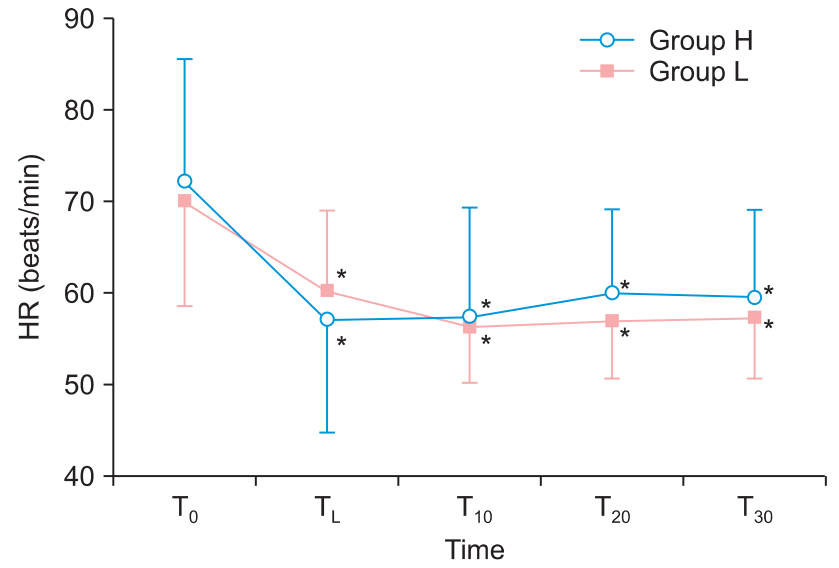

Fig. 2. Heart rate during sedation. ${ }^{*} \mathrm{P}<0.05$ compared to $\mathrm{T}_{0}$. Group $\mathrm{L}$ : loading dose $0.5 \mu \mathrm{g} / \mathrm{kg}$, Group $\mathrm{H}$ : loading dose $1.0 \mu \mathrm{g} / \mathrm{kg}$, $\mathrm{T}_{0}$ : start of anesthesia, $T_{L}$ : after loading, $T_{10}: 10$ minutes after $T_{L}, T_{20}$ : 20 minutes after $\mathrm{T}_{\mathrm{L}}, \mathrm{T}_{30}: 30$ minutes after $\mathrm{T}_{\mathrm{L}}$.

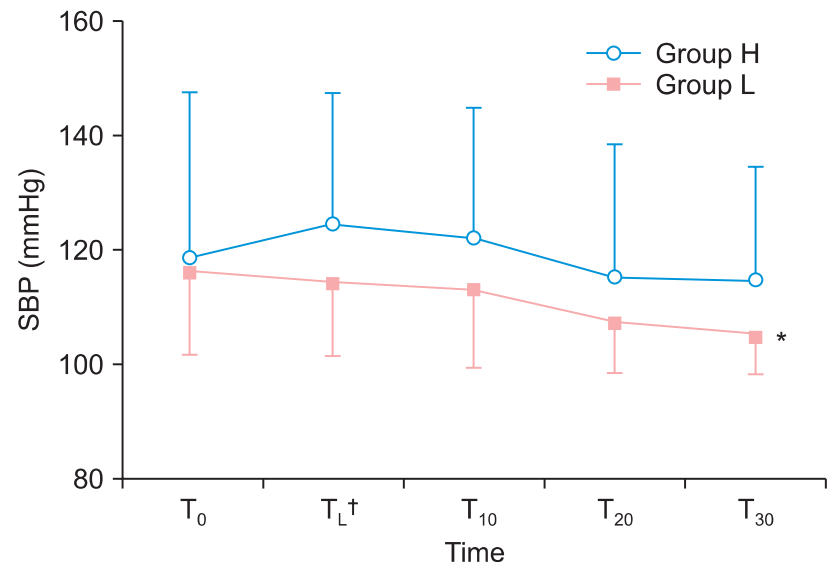

Fig. 3. Systolic blood pressure during sedation. ${ }^{*} \mathrm{P}<0.05$ compare to $\mathrm{T}_{0}$, ${ }^{\dagger} \mathrm{P}<0.05$ between two groups, Group L: loading dose $0.5 \mu \mathrm{g} / \mathrm{kg}$, Group H: loading dose $1.0 \mu \mathrm{g} / \mathrm{kg}, \mathrm{T}_{0}$ : start of anesthesia, $\mathrm{T}_{\mathrm{L}}$ : after loading, $\mathrm{T}_{10}: 10$ minutes after $\mathrm{T}_{\mathrm{L}}, \mathrm{T}_{20}: 20$ minutes after $\mathrm{T}_{\mathrm{L}}, \mathrm{T}_{30}: 30$ minutes after $\mathrm{T}_{\mathrm{L}}$.

nificant differences between two groups (Fig. 2).

Systolic blood pressure did not show any significant differences except at $T_{30}$ in group $L$, where SBP was significantly lower rather than $\mathrm{T}_{0}$ (Fig. 3). Between two groups, SBP value in both groups showed a significant difference only at $T_{L}$, SBP value of group L was lower than that of group $\mathrm{H}$ (Fig. 3).

There were no significant differences between two groups in the incidence of bradycardia, hypoxemia, hypotension and hypertension (Table 3).

Incidence of oral dryness, tachycardia, excessive bradycardia and use of atropine and ephedrine did not show any significant differences.

Ramsay score did not show any significant differences except at $T_{L}$ when the score of group $L$ was significantly lower than the score of group H (Fig. 4). 


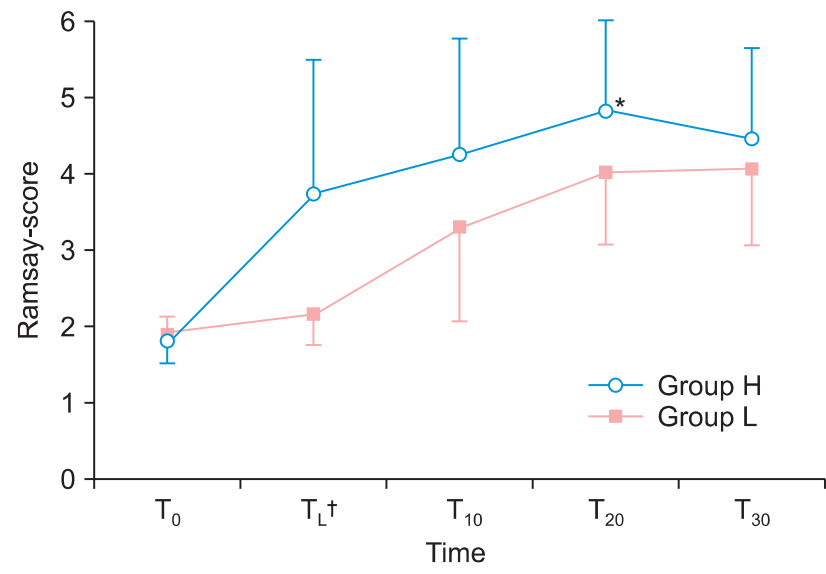

Fig. 4. Ramsay-score during sedation. ${ }^{*} \mathrm{P}<0.05$ compare to $\mathrm{T}_{0},{ }^{\dagger} \mathrm{P}<$ 0.05 between two groups, Group L: loading dose $0.5 \mu \mathrm{g} / \mathrm{kg}$, Group H: loading dose $1.0 \mu \mathrm{g} / \mathrm{kg}$, T0: start of anesthesia, $\mathrm{T}_{\mathrm{L}}$ : after loading, $\mathrm{T}_{10}: 10$ minutes after $T_{L}, T_{20}: 20$ minutes after $T_{L}, T_{30}: 30$ minutes after $T_{L}$.

\section{Discussion}

Dexmedetomidine is a highly selective alpha 2-agonist that is used in the operating room and ICU [7]. Its unique characteristics of powerful sedation without respiratory depression make dexmedetomidine one of the most useful drugs in sedative fields $[7,11]$.

In our study, both groups showed significantly lower BIS values compared to baseline after loading, although the breakpoint was different. In group $\mathrm{L}$, the significant difference revealed itself 10 minutes after loading, while in group $\mathrm{H}$ it occurred right after loading (Fig. 1). BIS values between the two groups did not show any significant differences except at $T_{10}$, where the BIS value of group $\mathrm{H}$ was lower than that of group L. Previous investigations commented that an increase in loading dose and plasma concentration of dexmedetomidine resulted in improved sedation [12]. In addition to affirmative results in the past, it has been suggested that dexmedetomidine has a dose-dependent sedation effect, which may be altered by the loading dose [13]. These results indicate that a higher loading dose of dexmedetomidine may lead to more rapid sedation. As faster sedation is one of the major goals in the use of dexmedetomidine, a loading dose of $1.0 \mu \mathrm{g} / \mathrm{kg}$ may be far superior to $0.5 \mu \mathrm{g} / \mathrm{kg}$ in terms of sedation. A recent trial indicated that a BIS value of 65 to 85 may be an optimal standard for sedation [14]. According to our data, group $\mathrm{H}$ showed faster entrance to BIS below 85 than group L.

Ramsay score differed significantly only at $\mathrm{T}_{\mathrm{L}}$, where the value of group L was lower than that of group $\mathrm{H}$. Group $\mathrm{H}$ showed successful entrance to the Ramsay score above 3 after $T_{L}$, while group $\mathrm{L}$ after $\mathrm{T}_{10}$. We have found reports that Ramsay score of 3 to 4 is optimal for sedation [15]. Also, this score roughly corresponds to BIS 69 to 81 , which is acceptable to our result as well [16]. The superiority of the higher loading dose in faster sedation is well reflected in our data.

HR values were significantly lower than the baseline value at all points, while no significant differences were shown between two groups. These data are consistent with previous investigations that dexmedetomidine has a great relation to the complication of bradycardia [7].

The SBP of the two groups showed significant differences at $\mathrm{T}_{\mathrm{L}}$, when the SBP of group $\mathrm{H}$ was higher than that of group $\mathrm{L}$. This corresponds to results of past research that indicated that a greater loading dose of dexmedetomidine may result in faster incidence of transient hypertension $[17,18]$.

In total, use of a higher loading dose of dexmedetomidine results in faster effects, whether sedation or cardiovascular features. These data suggest that the cardiovascular effects of dexmedetomidine are related to its concentration and dosing [19].

The subjectivity of the Ramsay score calls for attention however. Values such as SBP, HR, and BIS are perfectly numerated and can be defined objectively by anyone. However, the Ramsay score requires a small 'interview' and may differ by patient or questioner.

In conclusion, the $1 \mu \mathrm{g} / \mathrm{kg}$ loading dose of dexmedetomidine can lead to faster sedation without any severe complication. So, for rapid sedation after spinal anesthesia, a higher loading dose such as $1 \mu \mathrm{g} / \mathrm{kg}$ may be an optimal choice for this drug.

\section{Acknowledgments}

This work was supported by the research grant of Chungbuk National University in 2013.

\section{References}

1. Choi JW, Kim DW, In JH, Jung HS, Jeon YS, Lee JA, et al. Comparison of an intraoperative infusion of dexmedetomidine or fentanyl for the perioperative hemodynamics, achieving hypnosis and sedation and the postoperative pain control. Anesth Pain Med 2011; 6: 125-30.

2. Venn RM, Hell J, Grounds RM. Respiratory effects of dexmedetomidine in the surgical patients requiring intensive care. Crit Care 2000; 4: 302-8.

3. Gerlach AT, Dasta JF. Dexmedetomidine: an updated review. Ann Pharmacother 2007; 41: 245-52.

4. Hsu YW, Cortinez LI, Robertson KM, Keifer JC, Sum-Ping ST, Moretti EW, et al. Dexmedetomidine pharmacodynamics: part 1: crossover comparison of the respiratory effects of dexmedetomidine and remifentanil in healthy volunteers. Anesthesiology 2004; 101: 1066-76. 
5. Bhana N, Goa KL, McClellan KJ. Dexmedetomidine. Drugs 2000; 59: 263-8.

6. Lee SK. Clinical use of dexmedetomidine in monitored anesthesia care. Korean J Anesthesiol 2011; 61: 451-2.

7. Wang T, Ge S, Xiong W, Zhou P, Cang J, Xue Z. Effects of different loading doses of dexmedetomidine on bispectral index under stepwise propofol target-controlled infusion. Pharmacology 2013; 91: 1-6.

8. Herr DL, Sum-Ping ST, England M. ICU sedation after coronary artery bypass graft surgery: dexmedetomidine-based versus propofolbased sedation regimens. J Cardiothorac Vasc Anesth 2003; 17: 576-84.

9. Hoy SM, Keating GM. Dexmedetomidine: a review of its use for sedation in mechanically ventilated patients in an intensive care setting and for procedural sedation. Drugs 2011; 71: 1481-501.

10. Ramsay MA, Savege TM, Simpson BR, Goodwin R. Controlled sedation with alphaxalone-alphadolone. Br Med J 1974; 2: 656-9.

11. Kose EA, Honca M, Yilmaz E, Batislam E, Apan A. Comparison of effects of dexmedetomidine-ketamine and dexmedetomidinemidazolam combinations in transurethral procedures. Urology 2012; 79: 1214-9.

12. Ebert TJ, Hall JE, Barney JA, Uhrich TD, Colinco MD. The effects of increasing plasma concentration of dexmedetomidine in humans. Anesthesiology 2000; 93: 382-94.

13. Lee S, Kim BH, Lim K, Stalker D, Wisemandle W, Shin SG, et al. Pharmacokinetics and pharmacodynamics of intravenous dexmedetomidine in healthy Korean subjects. J Clin Pharm Ther 2012; 37: 698-703.

14. Hong GH. Monitoring and Anesthesia Record. In: Anesthesiology and Pain Medicine. 2nd ed. Edited by the Korean Society of Anesthesiologist: Seoul, Ryo Moon Gak. 2010, pp 142-3.

15. Strøm T. Sedation in the ICU. Dan Med J 2012; 59: B4458.

16. Mondello E, Siliotti R, Noto G, Cuzzocrea E, Scollo G, Trimarchi G, et al. Bispectral index in ICU: correlation with Ramsay Score on assessment of sedation level. J Clin Monit Comput 2002; 17: 271-7.

17. Maze M, Scarfini C, Cavaliere F. New agents for sedation in the intensive care unit. Crit Care Clin 2001; 17: 881-97.

18. Bloor BC, Ward DS, Belleville JP, Maze M. Effects of intravenous dexmedetomidine in humans. II. Hemodynamic changes. Anesthesiology 1992; 77: 1134-42.

19. Khan ZP, Ferguson CN, Jones RM. Alpha-2 and imidazoline receptor agonists. Their pharmacology and therapeutic role. Anaesthesia 1999; 54: 146-65. 